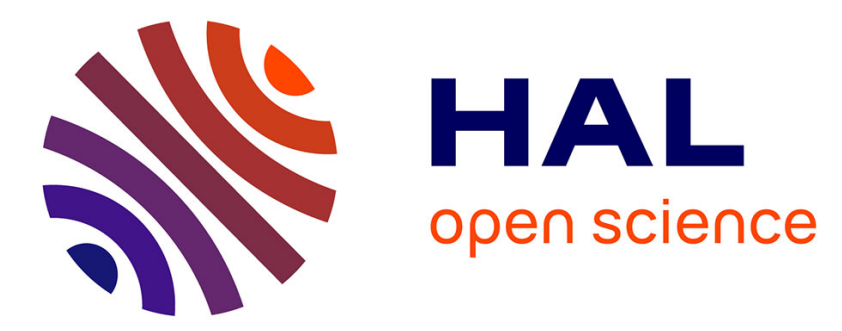

\title{
Stability, relaxometric and computational studies on Mn $2+$ complexes with ligands containing a cyclobutane scaffold
}

Oriol Porcar-Tost, Agnès Pallier, David Esteban-Gómez, Ona Illa, Carlos Platas-Iglesias, Éva Tóth, Rosa M Ortuño

\section{To cite this version:}

Oriol Porcar-Tost, Agnès Pallier, David Esteban-Gómez, Ona Illa, Carlos Platas-Iglesias, et al.. Stability, relaxometric and computational studies on Mn 2+ complexes with ligands containing a cyclobutane scaffold. Dalton Transactions, 2021, 50 (3), pp.1076-1085. 10.1039/D0DT03402A . hal-03442176

\section{HAL Id: hal-03442176 https://hal.science/hal-03442176}

Submitted on 23 Nov 2021

HAL is a multi-disciplinary open access archive for the deposit and dissemination of scientific research documents, whether they are published or not. The documents may come from teaching and research institutions in France or abroad, or from public or private research centers.
L'archive ouverte pluridisciplinaire $\mathbf{H A L}$, est destinée au dépôt et à la diffusion de documents scientifiques de niveau recherche, publiés ou non, émanant des établissements d'enseignement et de recherche français ou étrangers, des laboratoires publics ou privés. 


\title{
Dalton Transactions
}

\section{Stability, relaxometric and computational studies on $\mathrm{Mn}^{2+}$ complexes with ligands containing a cyclobutane scaffold}

Received 00th January 20xx, Accepted 00th January 20xx

DOI: $10.1039 / \times 0 \times x 00000 x$

www.rsc.org/

\author{
Oriol Porcar-Tost, ${ }^{a}$ Agnès Pallier, ${ }^{b}$ David Esteban-Gómez, ${ }^{c}$ Ona Illa, ${ }^{a}$ Carlos Platas-Iglesias, ${ }^{* c}$ Éva
} Tóth, ${ }^{*, b}$ and Rosa M. Ortuño*,a

\begin{abstract}
The stability constants of $\mathrm{Mn}^{2+}$ complexes with ligands containing a trans-1,2-cyclobutanediamine spacer functionalized with picolinate and/or carboxylate functions were determined using potentiometric titrations (25 $\mathrm{C}, 0.1 \mathrm{M} \mathrm{KCl}$ ). The stability constant of the complex wih the hexadentate ligand containing four acetate groups $\left(\mathbf{L 1}^{4-}, \log K_{\mathrm{MnL}}=10.26\right)$ is improved upon replacing one $\left(\mathbf{L 2}^{4-}, \log K_{\mathrm{MnL}}=14.71\right)$ or two $\left(\mathbf{L 3}^{4-}, \log K_{\mathrm{MnL}}=15.81,\right)$ carboxylate groups by picolinates. The $[\mathrm{MnL} 1]^{2-}$ complex contains a water molecule coordinated to the metal ion in aqueous solutions, as evidenced by ${ }^{1} \mathrm{H}$ NMRD studies and ${ }^{17} \mathrm{O}$ chemical shifts and transverse relaxation rates. The ${ }^{1} \mathrm{H}$ relaxivities determined at $60 \mathrm{MHz}\left(3.3\right.$ and $2.4 \mathrm{~mm}^{-1} \mathrm{~s}^{-1}$ at 25 and $37{ }^{\circ} \mathrm{C}$, respectively) are comparable to those of monohydrated complexes such as $[\mathrm{Mn}(\text { edta })]^{2-}$. The exchange rate of the inner-sphere water molecule $\left(k_{\mathrm{ex}}{ }^{298}=248 \times 10^{6} \mathrm{~s}^{-1}\right)$ is slightly lower than that of the edta ${ }^{4-}$ analogue. DFT calculations (M11/def2-TZVP) suggest that the water exchange reaction follows a dissociatively activated mechanism, providing activation parameters in reasonably good agreement with the experimental data. DFT calculations also show that the ${ }^{17} \mathrm{O}$ hyperfine coupling constant $\mathrm{A} / \hbar$ is affected slightly by changes in the $\mathrm{Mn}-\mathrm{O}_{\text {water }}$ distance and the orientation of the water molecule with respect to the Mn-O vector.
\end{abstract}

\section{Introduction}

The search for efficient and nontoxic contrast agents for magnetic resonance imaging (MRI) is a highly active field. Their value in diagnostics in general and, specifically, in theranostics confers these compounds with a great relevance in medicine and biomedical research. ${ }^{1}$

All clinical agents are complexes of $\mathrm{Gd}^{3+}$, which is explained by the great relaxation efficiency of this paramagnetic metal ion allowing for high image contrast. Their stability and kinetic inertness, however, might be limiting factors for clinical applications, because of the elevated toxicity of gadolinium potentially released from the complexes in vivo. Nephrogenic systemic fibrosis, a pathology directly linked to $\mathrm{Gd}$ injections, and $\mathrm{Gd}$ accumulation in the brain and bones of patients with frequent exposure to contrast-enhanced MRI have recently led to serious restrictions in their clinical use. ${ }^{2}$

These concerns reinforced the exploration of other, more

\footnotetext{
a. Departament de Química, Universitat Autònoma de Barcelona, 08193 Cerdanyola del Vallès, Barcelona, Spain.E-mail: rosa.ortuno@uab.es

${ }^{b}$ Centre de Biophysique Moléculaire, UPR 4301, CNRS, Universitéd'Orléans, rue Charles Sadron, 45071 Orléans Cedex 2, France.E-mail: eva.jakabtoth@cnrs.fr c. Universidade da Coruña, Centro de Investigacións Científicas Avanzadas (CICA) and Departamento de Química, Facultade de Ciencias, 15071, A Coruña, Galicia, Spain.E-mail: carlos.platas.iglesias@udc.es

+ Electronic supplementary information (ESI) available: Potentiometric experiments and structural details of the structures obtained with DFT. See DOI: $10.1039 / \times 0 \times x 00000 x$
}

biocompatible paramagnetic metal ions which are able to form stable complexes with high relaxivity. $\mathrm{Mn}^{2+}$ is an obvious candidate to replace $\mathrm{Gd}^{3+}$. It is a good relaxation agent due to its $d^{5}$ electronic configuration that results in slow relaxation times of the electron spin, ${ }^{3,4}$ while being an essential element, its toxicity profile is better than that of gadolinium. ${ }^{5}$ In recent years, many comprehensive studies have been conducted on $\mathrm{Mn}^{2+}$ complexes to relate the stability, kinetic and relaxometric properties to structural elements and denticity of the chelating ligands, and some highly effective $\mathrm{Mn}^{2+}$-based compounds have been lately reported as promising potential contrast agents.3 $3^{6,7}$

High kinetic inertness is particularly difficult to achieve for $\mathrm{Mn}^{2+}$-chelates. The rigidity of the chelators has been recognized to improve resistance to dissociation, as it was evidenced some years ago for the cyclohexyl derivative $[\mathrm{Mn}(\mathrm{cdta})]^{2-}$ (Scheme 1). ${ }^{8,9}$ Likewise, both the trans-1,2cyclohexylene backbone and the pyridine function are crucial and rigidifying structural features to provide slow dissociation of the $\left[\mathrm{Mn}(\text { pyc3a) }]^{-}\right.$complex3 (Scheme 1) which has successfully passed to in vivo experiments. ${ }^{10}$ Very recently, a 2,4-pyridyl-disubstituted bispidol ligand and its $\mathrm{Mn}^{2+}$ chelate have been reported. The $\mathrm{Mn}^{2+}$-bispidine complex has shown an unprecedented kinetic inertness provided by its highly rigid structure. It is monohydrated, has good relaxation efficiency, and preliminary biodistribution studies showed rapid renal clearance when injected into healthy mice. ${ }^{11}$ 
In a previous work, we have investigated three highly rigid ligands containing a cyclobutane ring in the backbone, namely $\mathrm{H}_{4}$ cbdta $\left(\mathrm{H}_{4} \mathrm{~L} \mathbf{1}\right), \mathrm{H}_{4}$ cbddapa $\left(\mathrm{H}_{4} \mathrm{~L} \mathbf{L}\right)$ and $\mathrm{H}_{4}$ cbddapa $\left(\mathrm{H}_{4} \mathrm{~L} \mathbf{L}\right)$ (Scheme 1), ${ }^{12}$ which are hexa-, hepta-, and octadentate, respectively. With $\mathrm{Gd}^{3+}$, they form hydrated complexes that show relaxivity values and kinetic inertness comparable with

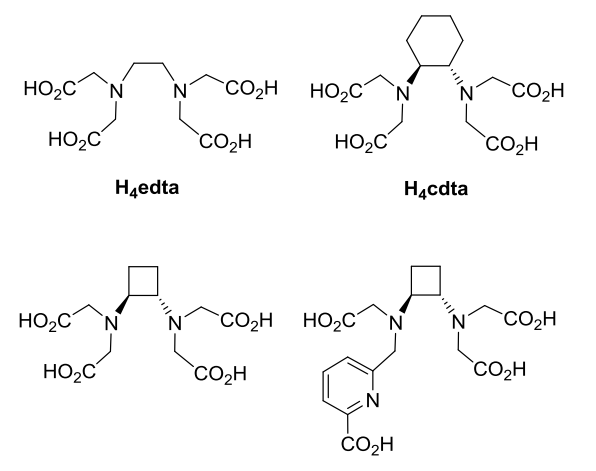

$\mathrm{H}_{4} \mathrm{cbdta}=\mathrm{H}_{4} \mathrm{~L} 1$
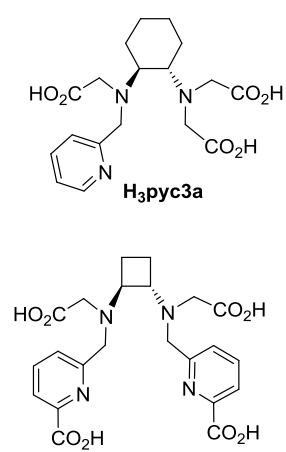

$\mathrm{H}_{4}$ cbddadpa $=\mathrm{H}_{4} \mathrm{~L} 3$
Scheme 1. Chemical structure of the ligands discussed in this work.

some relevant $\mathrm{Gd}^{3+}$ complexes such as chelates with octapa ${ }^{4-}$, cddadpa $^{4-}$, or $\mathrm{dtpa}^{5-}$ (octapa $^{4-}=6,6^{\prime}$-[(ethane-1,2-diylbis((carboxymethyl)azanediyl))bis(methylene)]-dipicolinic acid; $\mathrm{dtpa}^{5-}=$ diethylenetriamine-pentaacetate). ${ }^{13}$ Although the thermodynamic stability of the picolinate containing complexes $[\mathrm{Gd}(\mathbf{L 2})]^{-}$and $[\mathrm{Gd}(\mathbf{L} \mathbf{3})]^{-}$was similar, their dissociation kinetics was very different and the monohydrated $[\mathrm{Gd}(\mathbf{L} \mathbf{3})]^{-}$was considerably more labile than the bishydrated $[\mathrm{Gd}(\mathbf{L 2})]^{-}$, as a result of the significant kinetic activity of the protonated picolinate function to promote dissociation of the complex. This was an uncommon example of kinetic-inertness enhancement by decreasing ligand denticity. Furthermore, a structural analysis by means of density functional theory (DFT) calculations suggested that the large bite angle imposed by the rigid trans-1,2-cyclobutanediamine spacer could allow the coordination of larger metal ions providing chelates potentially apt for biomedical applications.

In this work, we present stability, relaxometric and computational studies on $[\mathrm{Mn}(\mathbf{L} \mathbf{1})]^{2-},[\mathrm{Mn}(\mathbf{L 2})]^{2-}$ and $[\mathrm{Mn}(\mathbf{L} \mathbf{3})]^{2-}$ complexes. Several picolinate-derivatives have been previously investigated for $\mathrm{Mn}^{2+}$ complexation; ${ }^{6,14}$ the present work ascertained again the role of the picolinate functions in $\mathbf{L 2}$ and $\mathbf{L} \mathbf{3}$ to increase complex stability by increasing the ligand denticity. $[\mathrm{Mn}(\mathbf{L} \mathbf{1})]^{2-}$ has been studied in more depth regarding the water exchange rate and compared with related $\mathrm{Mn}^{2+}$ complexes described in the literature. The experimental results have been complemented with DFT calculations to understand the influence of the rigidity of the ligand spacer on the water exchange process and to provide helpful information for the rational design of $\mathrm{Mn}^{2+}$ chelates as potential MRI contrast agents with improved characteristics.

\section{Results and discussion}

Thermodynamic stability. The protonation constants of the ligands determined at $25{ }^{\circ} \mathrm{C}$ in $0.1 \mathrm{M} \mathrm{KCl}$ were reported previously, and they are subsequently $9.66,5.84,3.06,2.08$ and 1.71 for $\mathbf{L 1}^{4}$,, 9.58 , 6.00, 3.78, 2.32 and 2.07 for $\mathbf{L 1}^{4-}$ and 8.89, 6.61, 4.26, 2.97 and 2.79 for $\mathbf{L 3}^{\mathbf{4}}{ }^{12}$ Herein we report the stability constants of the corresponding $\mathrm{Mn}^{2+}$ complexes determined under the same conditions using potentiometric titrations (Fig. S1, ESIt). The stability and protonation constants of the complexes are compared with data reported for related systems in Table $1 .{ }^{15-17}$ The stability constant

Table 1. Stability and protonation constants of $[\mathrm{Mn}(\mathbf{L} \mathbf{1})]^{2-}$, $[\mathrm{Mn}(\mathrm{L2} 2)]^{2-},[\mathrm{Mn}(\mathrm{L} \mathbf{3})]^{2-}$ and related $\mathrm{Mn}^{2+}$ complexes $\left(25^{\circ} \mathrm{C}, 0.1 \mathrm{M}\right.$ $\mathrm{KCl})$.

\begin{tabular}{|c|c|c|c|}
\hline & $\log K_{\mathrm{MnL}}$ & $\log K_{\mathrm{MnHL}}$ & $\mathrm{pMn}^{f}$ \\
\hline$[\mathrm{Mn}(\mathbf{L} \mathbf{1})]^{2-}$ & $10.26 \pm 0.01^{a}$ & $4.07 \pm 0.02^{a}$ & 6.50 \\
\hline$[\mathrm{Mn}(\mathbf{L 2})]^{2-}$ & $14.71 \pm 0.01^{a}$ & $3.25 \pm 0.01^{a}$ & 8.76 \\
\hline$[\mathrm{Mn}(\mathbf{L} \mathbf{3})]^{2-}$ & $15.81 \pm 0.07^{a}$ & $3.60 \pm 0.05^{a, b}$ & 9.62 \\
\hline$[\mathrm{Mn}(\text { edta })]^{2-}$ & $12.46 ;^{\bar{c}} 12.61^{d}$ & $2.95^{\bar{c}} 2.90^{d}$ & 7.83 \\
\hline$[\mathrm{Mn}(\mathrm{cdta})]^{2-}$ & $14.32 ;^{c} 14.69^{d}$ & $2.90 ;^{c} 2.42^{d}$ & 9.90 \\
\hline$[\mathrm{Mn}(\text { pyc3a })]^{-}$ & $14.14^{e}$ & $2.43^{e}$ & 8.58 \\
\hline
\end{tabular}
$3.35+0.05$ was also calculated. ${ }^{c}$ Data from Ref $15 .{ }^{d}$ Data from Ref $16 .{ }^{e}$ Data from Ref $17 .{ }^{f}$ Defined as $-\log \left[\mathrm{Mn}^{2+}\right]_{\text {free }}$ at $\mathrm{pH} 7.4$ for $\left[\mathrm{Mn}^{2+}\right]_{\text {tot }}=[\mathrm{L}]_{\text {tot }}=10^{-5}$ $M$.

of $[\mathrm{Mn}(\mathbf{L} \mathbf{1})]^{2-}$ is two $\log K$ units lower than that of the edta ${ }^{4-}$ complex, and four $\log K$ units lower than those of the cyclohexyl derivatives $[\mathrm{Mn}(\mathrm{cdta})]^{2-}$ and $\left[\mathrm{Mn}(\text { pyc3a) }]^{-}\right.$. Replacing one of the carboxylate groups of $\mathbf{L 1}^{4-}$ by a picolinate unit promotes a dramatic increase of the stability constant, an effect that is related, at least in part, with the increased ligand denticity. Increasing further ligand denticity by incorporating a second picolinate unit in $[\mathrm{Mn}(\mathbf{L} \mathbf{3})]^{2-}$ results in an additional increase of the stability constant by $\sim 1 \log K$ unit. The stability constant of the $[\mathrm{Mn}(\mathbf{L} 3)]^{2-}$ complex is rather high for a $\mathrm{Mn}^{2+}$ complex, comparable to those of macrocyclic complexes such as $[\mathrm{Mn}(\mathrm{do} 2 \mathrm{a})]^{18}$

The stabilities of complexes formed with ligands of different basicities are generally compared by using $\mathrm{pM}$ values $(\mathrm{pMn}$ $=-\log \left[\mathrm{Mn}^{2+}\right]_{\text {free }}$ ), which for $\mathrm{Mn}^{2+}$ complexes are typically calculated at $\mathrm{pH} 7.4$ for $10^{-5} \mathrm{M}$ total concentrations of both the ligand and the metal ion. ${ }^{19}$ The results confirm that the $[\mathrm{Mn}(\mathbf{L 1})]^{2-}$ complex presents a rather low stability compared with $\left[\mathrm{Mn}(\text { edta) }]^{2-}\right.$, $[\mathrm{Mn}(\mathrm{cdta})]^{2-}$ and $[\mathrm{Mn}($ pyc3a) $]$. The pMn value of the complex with heptadentate $\mathbf{L 2}^{\mathbf{A}^{-}}$is however comparable or higher than those of $\left[\mathrm{Mn}(\text { edta) }]^{2-}\right.$ and $\left[\mathrm{Mn}(\right.$ pyc3a) $]$. The complex with octadentate $\mathbf{L 3}^{4-}$ is even more stable, with a $\mathrm{pMn}$ value comparable to that of $[\mathrm{Mn}(\mathrm{cdta})]^{2-}$. These results demonstrate that the incorporation of picolinate groups into the ligand scaffold is beneficial in terms of increasing complex stability. The speciation diagrams calculated with the thermodynamic stability constants highlight this effect. Indeed, the $[\mathrm{Mn}(\mathbf{L} \mathbf{1})]^{2-}$ complex is stable only above $\mathrm{pH} \sim 6$, while below this $\mathrm{pH}$ dissociation occurs, together with the formation of a protonated complex species (Fig. 1). [Mn(L2) $]^{2-}$ is stable in a broader $\mathrm{pH}$ range, forming a protonated form below $\mathrm{pH} \sim 6$, and dissociating significantly only below $\mathrm{pH} 4$. The $[\mathrm{Mn}(\mathbf{L} \mathbf{3})]^{2-}$ complex dissociates even at lower $\mathrm{pH}$ (below $\mathrm{pH} \sim 3.5$ ), while forming two protonated species. The considerably higher stability of $[\mathrm{Mn}(\mathbf{L} \mathbf{2})]^{2-}$ compared to $[\mathrm{Mn}(\mathbf{L} \mathbf{1})]^{2-}$ is likely related to the coordination of all seven donor atoms of $\mathbf{L 2}^{\mathbf{4}^{-}}$to the metal ion, as 
supported by DFT calculations (Fig. S2, ESI+). In [Mn(L3)] ${ }^{2-}$, DFT calculations suggest that the metal ion is seven-coordinated, with the metal coordination environment being fulfilled by the two amine $\mathrm{N}$ atoms, the donor atoms of the picolinate groups and an oxygen atom of one of the carboxylate groups. The second carboxylate group likely remains uncoordinated (Fig. S3, ESI+).
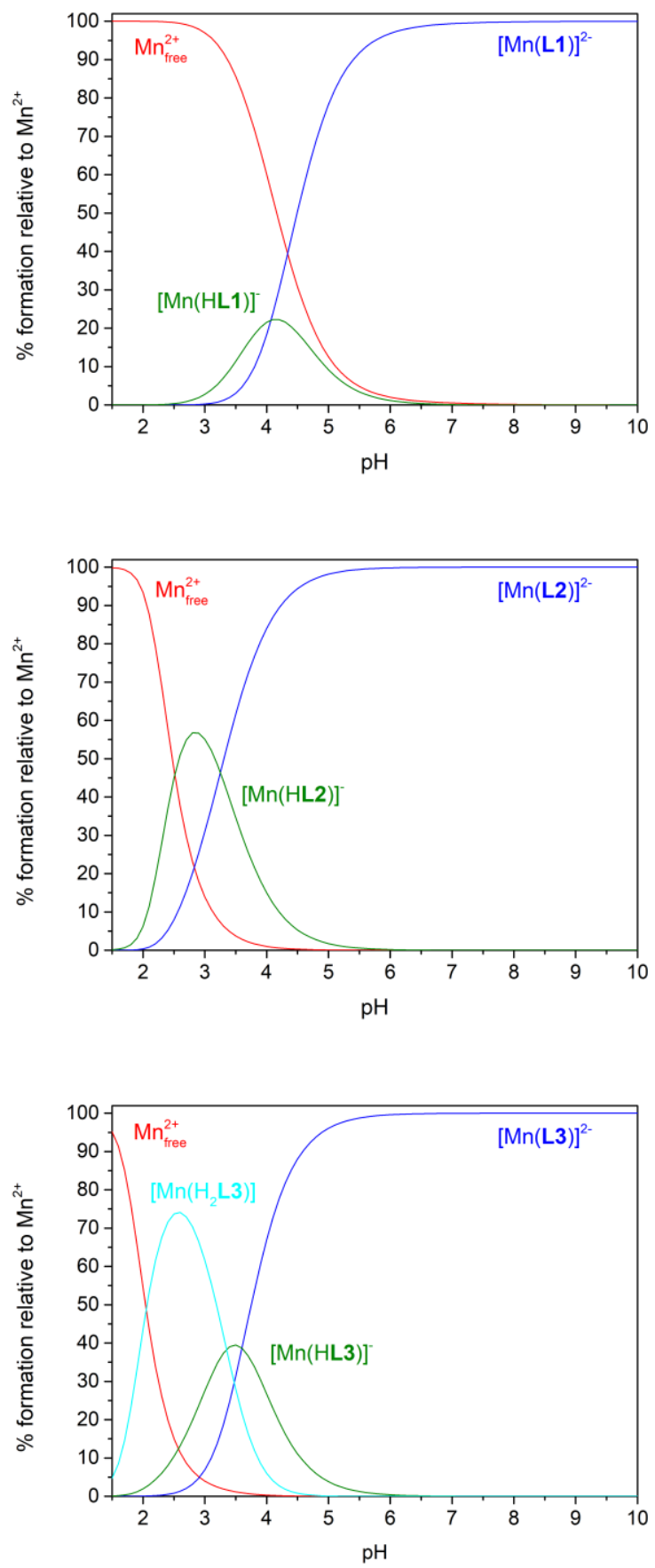

Figure 1. Species distribution curves of the $\mathrm{Mn}^{2+}: \mathrm{L}^{4-}$ systems $(\mathbf{L}=\mathbf{L} \mathbf{1}, \mathbf{L} \mathbf{2}$ or $\mathbf{L 3})$. $\left[\mathrm{Mn}^{2+}\right]_{\mathrm{tot}}=[\mathrm{L}]_{\mathrm{tot}}=10^{-3} \mathrm{M}$.

Relaxivity and ${ }^{17} \mathrm{O}$ NMR measurements. The efficacy of a potential contrast agent in vitro is determined by its proton relaxivity $\left(r_{1}\right)$, which denotes the enhancement of the longitudinal relaxation rate of water proton nuclei promoted by the paramagnetic ion at $1 \mathrm{mM}$ concentration. Among the three $\mathrm{Mn}^{2+}$ complexes, only $[\mathrm{Mn}(\mathbf{L 1})]^{2-}$ is expected to contain inner sphere water, therefore relaxivities were measured for this chelate. The relaxivity determined for $[\mathrm{Mn}(\mathbf{L} \mathbf{1})]^{2-}$ at $\mathrm{pH} 7.4$ $\left(37^{\circ} \mathrm{C}, 60 \mathrm{MHz}\right.$ ) is $2.4 \mathrm{mM}^{-1} \mathrm{~s}^{-1}$, a value that compares well with those reported for monohydrated complexes of similar size, such as $[\mathrm{Mn}(\text { edta })]^{2-},[\mathrm{Mn}(\mathrm{cdta})]^{2-}$ and $\left[\mathrm{Mn}(\text { pyc3a) }]^{-}(2.1-\right.$ $2.2 \mathrm{mM}^{-1} \mathrm{~s}^{-1}$ at $\mathrm{pH} 7.4,37{ }^{\circ} \mathrm{C}$ and $60 \mathrm{MHz}$, Table 2).3.8 $r_{1}$ decreases with increasing temperature, as usually observed for small $\mathrm{Mn}^{2+}$ complexes, which implies that relaxivity is limited by fast rotation.

Table 2. Relaxivity values of $[\mathrm{Mn}(\mathbf{L} \mathbf{1})]^{2-}$ and related complexes taken from the literature. ${ }^{a}$

\begin{tabular}{clll}
\hline & $r_{1}, 25^{\circ} \mathrm{C}$ & $r_{1}, 37^{\circ} \mathrm{C}$ & $q$ \\
{$[\mathrm{Mn}(\mathrm{L} 1)]^{2-}$} & 3.3 & 2.4 & 1 \\
{$[\mathrm{Mn}(\text { edta })]^{2-}$} & $2.8^{b}$ & $2.2^{c}$ & 1 \\
{$[\mathrm{Mn}(\mathrm{cdta})]^{2-}$} & - & $2.1^{c}$ & 1 \\
$\frac{[\mathrm{Mn}(\text { pyc3a })]^{-}}{\text {Data recorded at } 60 \mathrm{MHz}, 1.4 \mathrm{~T}^{b} \text { Data from Ref 8. }{ }^{c} \text { Data from Ref. 3 }}$ & - & $2.1^{c}$ & 1
\end{tabular}

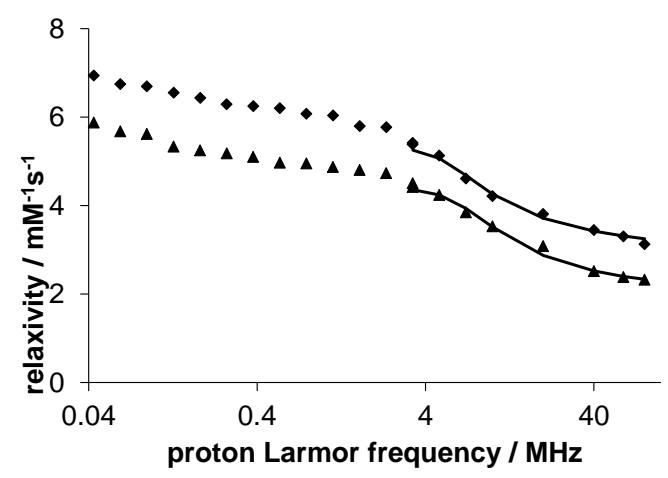

Figure $2 .{ }^{1} \mathrm{H}$ NMRD profiles recorded from a $3.29 \mathrm{mM}[\mathrm{Mn}(\mathbf{L} \mathbf{1})]^{2-}$ solution at $25^{\circ} \mathrm{C}(\bullet)$ and $37{ }^{\circ} \mathrm{C}(\mathbf{\Delta})$ at $\mathrm{pH}=7.4$. A $15 \%$ ligand excess was used to ensure full complexation of the metal ion. The lines represent a fit as explained in the text.

The ${ }^{1} \mathrm{H}$ NMRD profiles recorded from an aqueous solution of $[\mathrm{Mn}(\mathbf{L 1})]^{2-}$ at 25 and $37{ }^{\circ} \mathrm{C}$ present a dispersion in the range 2$40 \mathrm{MHz}$, which is typical of small $\mathrm{Mn}^{2+}$ complexes (Figure 2).9 A second faint dispersion at $\sim 0.1 \mathrm{MHz}$ that could be related to the presence of a small amount of free $\mathrm{Mn}^{2+}$, as the $\left[\mathrm{Mn}\left(\mathrm{H}_{2} \mathrm{O}\right)_{6}\right]^{2+}$ complex presents a second dispersion in this region with a sharp increase of relaxivity $\left(r_{1} \sim 21\right.$ and $64 \mathrm{mM}^{-1}$ $s^{-1}$ at 1 and $0.01 \mathrm{MHz}$, respectively, $\left.25^{\circ} \mathrm{C}\right) \cdot{ }^{20,21}$ However, the amount of free $\mathrm{Mn}^{2+}$ present in solution under the conditions used to record NMRD profiles is below $0.1 \mu \mathrm{M}$, as calculated on the basis of the thermodynamic stability constant. Thus, this slight relaxivity increase at low field could rather originate from a small scalar contribution, as observed for a few $\mathrm{Mn}^{2+}$ complexes other than the aqua ion. ${ }^{22}$ The relaxivity measured at $1 \mathrm{MHz}$ and $25{ }^{\circ} \mathrm{C}$ was used to estimate the number of coordinated water molecules $q$ using the empirical equation Eq (1), which relates the relaxivity to $q$ and the molecular weight of the complex: ${ }^{23}$

$$
q=\frac{r_{1}(1 \mathrm{MHz})}{9.16\left\{1-e^{\left(-2.97 \times F W \times 10^{-3}\right)}\right\}}
$$


This estimation gives a $q$ value of 1.0 , which confirms the monohydrated state of $\mathrm{Mn}^{2+}$ in $[\mathrm{Mn}(\mathbf{L 1})]^{2-}$. This suggests the coordination of the ligand in a hexadentate manner in addition to the coordinated water molecule, as observed in the X-ray structures of the $[\mathrm{Mn}(\text { edta })]^{2-}$ and $[\mathrm{Mn}(\mathrm{cdta})]^{2-}$ complexes. ${ }^{24}$
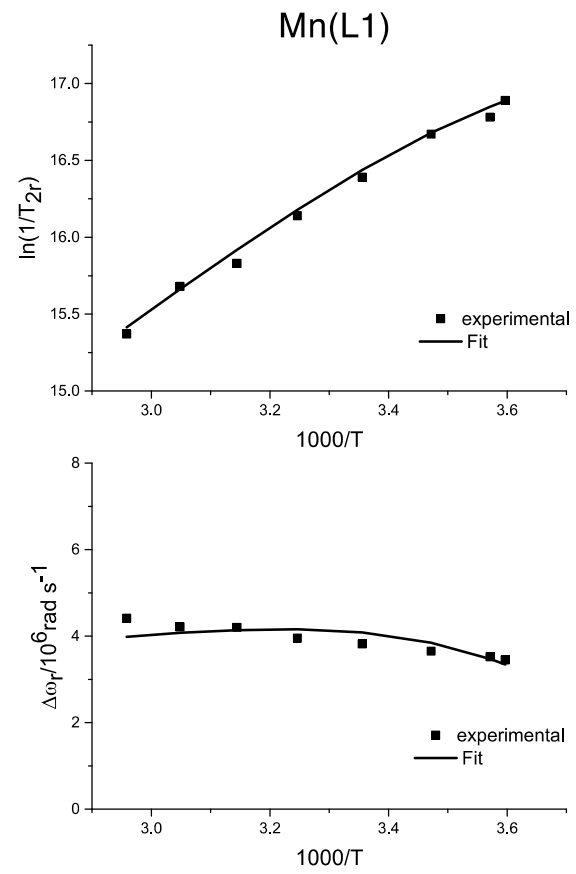

Figure 3. Reduced transverse ${ }^{17} \mathrm{O} N M R$ relaxation rates (top) and ${ }^{17} \mathrm{O} N M R$ chemical shifts (bottom) of a $4.9 \mathrm{mM}$ solution of $[\mathrm{Mn}(\mathbf{L 1})]^{2-}$ at $\mathrm{pH}=7.0$. The lines represent the simultaneous fit.

One of the most important parameters that affect the relaxivity of paramagnetic metal complexes is the exchange rate of the coordinated water molecule(s) with bulk water. Water exchange is relatively slow in the $\left[\mathrm{Mn}\left(\mathrm{H}_{2} \mathrm{O}\right)_{6}\right]^{2+}$ complex $\left(k_{\mathrm{ex}}{ }^{298}=28 \times 10^{6}\right.$ $\left.\mathrm{s}^{-1}\right),{ }^{20,25}$ and it is generally accelerated by coordination of polyaminopolycarboxylate ligands. We thus measured ${ }^{17} \mathrm{O}$ NMR transverse relaxation rates and chemical shifts on an aqueous solution of $[\mathrm{Mn}(\mathbf{L} \mathbf{1})]^{2-}$ at $\mathrm{pH}$ 7.0. The transverse relaxation rates are dominated by the scalar mechanism, which depends on the hyperfine coupling constant, $A / \hbar$, the water exchange rate, $k_{\mathrm{ex}}{ }^{298}$, and the longitudinal relaxation time of the electron spin, $T_{1 \mathrm{e}}{ }^{26}$ The reduced transverse relaxation rates $\left(T_{2 r}\right)$ increase with decreasing temperature (Figure 3), a situation that is characteristic of systems in the fast exchange regime. ${ }^{27}$ Under these conditions, $T_{2 r}$ is determined by all of these three parameters. On the other hand, the reduced ${ }^{17} \mathrm{O} N M R$ shifts $\Delta \omega_{\mathrm{r}}$ provide direct information on $A / \hbar$. The simultaneous fit of the chemical shift and relaxation data provided the parameters listed in Table 3.

The $k_{\mathrm{ex}}{ }^{298}$ value determined for $[\mathrm{Mn}(\mathbf{L} \mathbf{1})]^{2-}\left(248 \pm 12 \times 10^{6} \mathrm{~s}^{-1}\right)$ lies in between those reported for $[\mathrm{Mn}(\text { edta })]^{2-}\left(k_{\mathrm{ex}}{ }^{298}=471 \times 10^{6}\right.$ $\left.\mathrm{s}^{-1}\right) 8$ and $[\mathrm{Mn}(\mathrm{cdta})]^{2-}\left(k_{\mathrm{ex}}{ }^{298}=220 \times 10^{6} \mathrm{~s}^{-1}\right) .{ }^{28}$ The [Mn(pyc3a)] complex presents a somewhat lower water exchange, presumably due to its reduced negative charge. The water exchange process for most of these complexes is characterized by positive values of the activation entropy $\left(\Delta s^{\ddagger}\right)$, which suggests a dissociatively activated mechanism. For $[\mathrm{Mn}(\mathbf{L 1})]^{2-}$, the activation entropy has a small negative value which points to an interchange mechanism; however, we should note that $\Delta S^{\ddagger}$ can be obtained with a large error. Therefore, if available, the activation volumes should be rather used to conclude on the mechanism. The positive activation volume reported in the literature for $[\mathrm{Mn}(\mathrm{cdta})]^{2-}\left(\Delta V^{\ddagger}=+9.4 \mathrm{~cm}^{3}\right.$ $\left.\mathrm{mol}^{-1}\right)^{29}$ confirmed the dissociative character of the water exchange reaction. The $\Delta V^{*}$ value reported for $\left[\mathrm{Mn}(\text { edta) }]^{2-}\right.$ is however considerably lower $\left(+3.4 \mathrm{~cm}^{3} \mathrm{~mol}^{-1}\right)$, suggesting that the rigidity of the ligand spacer influences the mechanism of water exchange. The value of the hyperfine coupling constant $A / \hbar$ obtained from the fit $\left(-37.1 \pm 0.6 \times 10^{6} \mathrm{rad} \mathrm{s}^{-1}\right)$ is very similar to those reported for related systems, $8^{, 28}$ which confirms that the number of coordinated water molecules assumed in the analysis is correct $(q=1)$.

In order to obtain information on the rotational dynamics of the complex, the ${ }^{1} \mathrm{H}$ NMRD data have been analysed by using the Solomon-Bloembergen-Morgan (SBM) theory and fixing the rate and the activation enthalpy of the water exchange to the values determined from the ${ }^{17} \mathrm{O}$ NMR measurements. Relaxivities only above $3.5 \mathrm{MHz}$ have been included in this fit, within the validity of the SBM approach to describe dynamic processes like water exchange and rotational motion. In addition, some other parameters have been also fixed in the fit: the distances between the $\mathrm{Mn}$ and the water protons in the inner and outer coordination sphere, $r_{\mathrm{MnH}}$ and $a_{\mathrm{MnH}}$ to 2.83 and $3.6 \AA$, respectively, and the diffusion coefficient and its activation energy to $D_{\mathrm{MnH}}{ }^{298}=26 \times 10^{10}$ $\mathrm{m}^{2} \mathrm{~s}^{-1}$ and $E_{\mathrm{DMnH}}=18 \mathrm{kJmol}^{-1}$. For the parameters describing electron spin relaxation we calculated $\tau_{v}^{298}=37 \pm 2$ ps and $\Delta^{2}=$ $\left.(0.7 \pm 0.1) \times 10^{20} \mathrm{~s}^{-2}\right)$. The most important information obtained from this fit is the rotational correlation time, $\tau_{R}^{298}=74 \pm 2 \mathrm{ps}\left(E_{\mathrm{R}}=25\right.$ $\left.\mathrm{kJmol}^{-1}\right)$, which is reasonable for a small molecular weight chelate. The fitted curves are presented in Figure 2.

Table 3. Parameters obtained in the fitting of ${ }^{17} \mathrm{O} N M R$ data of $\left[\mathrm{Mn}\left(\mathrm{L}^{1}\right)\right]^{2-}$ compared to literature data for $\left[\mathrm{Mn}(\text { edta) }]^{2-},[\mathrm{Mn}(\mathrm{cdta})]^{2-}\right.$ and $\left[\mathrm{Mn}(\text { pyc3a) }]^{-}\right.$.

\begin{tabular}{|c|c|c|c|c|}
\hline & {$[\mathrm{Mn}(\mathrm{L} 1)]^{2-}$} & 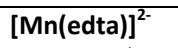 & 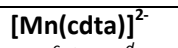 & [Mn(pyc3a)] \\
\hline$k_{e x}^{298} / 10^{6} s^{-1}$ & $248 \pm 12$ & $410^{a} / 471^{b}$ & $140^{c} / 220^{d}$ & $89.6^{e}$ \\
\hline$\Delta H^{\ddagger} / \mathrm{kJ} \mathrm{mol}^{-1}$ & $21.5 \pm 1.8$ & $36.6^{a} / 33.5^{b}$ & $42.5^{c} / 33.2^{d}$ & $37.2^{e}$ \\
\hline$\Delta S^{\ddagger} / \mathrm{J} \mathrm{K}^{-1} \mathrm{~mol}^{-1}$ & $-12 \pm 6$ & $+43^{a}$ & $+54^{c}$ & +32 \\
\hline$\Delta V^{ \pm} / \mathrm{cm}^{3} \mathrm{~mol}^{-1}$ & - & $+3.4^{a}$ & $+9.4^{c}$ & - \\
\hline$A_{0} / \mathrm{h} / 10^{6} \mathrm{rad} \mathrm{s}^{-1 e}$ & $-37.1 \pm 0.6$ & $-36.6^{a} /-33.5^{b}$ & $-26.4^{c} /-31.4^{d}$ & $-28.7^{e}$ \\
\hline $1 / T_{1 \mathrm{e}}{ }^{298}\left(10^{6} \mathrm{~s}^{-1}\right)$ & $30 \pm 3$ & - & - & - \\
\hline
\end{tabular}

${ }^{a}$ Data from Ref 27. ${ }^{b}$ Data from Ref $8 .{ }^{c}$ Data from Ref 29. ${ }^{d}$ Data from Ref $28 .{ }^{e}$ Data from Ref 3. 
Table 4. ${ }^{17} \mathrm{O}$ hyperfine coupling constants and water exchange parameters of the coordinated water molecules obtained with DFT calculations for the $\left[\mathrm{Mn}\left(\mathrm{L}^{1}\right)\right]^{2-},[\mathrm{Mn}(\text { edta })]^{2-},[\mathrm{Mn}(\mathrm{cdta})]^{2-}$ and $[\mathrm{Mn}(\text { pyc3a })]^{-}$complexes. ${ }^{a}$

\begin{tabular}{|c|c|c|c|c|}
\hline & {$[\mathrm{Mn}(\mathrm{L1})]^{2-}$} & {$\left[\mathrm{Mn}(\text { edta) }]^{2-}\right.$} & {$[\mathrm{Mn}(\mathrm{cdta})]^{2-}$} & [Mn(pyc3a)] \\
\hline$r_{\mathrm{MnO}} / \AA ̊$ & 2.253 & 2.260 & 2.271 & 2.253 \\
\hline$r_{\mathrm{MnO}}(\mathrm{TS}) / \AA ̊$ & 3.382 & $3.339 / 2.760^{b}$ & 3.316 & 3.320 \\
\hline$\Delta H^{\ddagger} / \mathrm{kJ} \mathrm{mol}^{-1}$ & 28.0 & $27.95 / 15.6$ & 25.3 & 28.6 \\
\hline$\Delta S^{\ddagger} / \mathrm{J} \mathrm{K}^{-1} \mathrm{~mol}^{-1}$ & +6.1 & $+7.4 /-31.9^{b}$ & +0.2 & +2.95 \\
\hline$\Delta G_{298}^{\ddagger} / \mathrm{kJ} \mathrm{mol}^{-1}$ & 26.2 & $25.75 / 25.1^{b}$ & 25.2 & 27.7 \\
\hline$A_{0} / \mathrm{h} / 10^{6} \mathrm{rad} \mathrm{s}^{-1 e}$ & -37.3 & -35.8 & -36.0 & -39.8 \\
\hline$k_{e x}^{298} / 10^{6} s^{-1 a}$ & 163 & $198 / 255^{b}$ & 241 & 90 \\
\hline
\end{tabular}

a Data obtained from calculations on the $\left[\mathrm{Mn}(\mathrm{L1})\left(\mathrm{H}_{2} \mathrm{O}\right)\right]^{2-} \cdot 5 \mathrm{H}_{2} \mathrm{O},\left[\mathrm{Mn}\left(\text { edta) }\left(\mathrm{H}_{2} \mathrm{O}\right)\right]^{2-} \cdot 5 \mathrm{H}_{2} \mathrm{O},\left[\mathrm{Mn}(\mathrm{cdta})\left(\mathrm{H}_{2} \mathrm{O}\right)\right]^{2-} \cdot 5 \mathrm{H}_{2} \mathrm{O}\right.$ and $\left[\mathrm{Mn}(\mathrm{pyc} 3 \mathrm{a})\left(\mathrm{H}_{2} \mathrm{O}\right)\right]^{-} \cdot 5 \mathrm{H}_{2} \mathrm{O}$ systems. ${ }^{b}$ Activation parameters obtained for the associative pathway (see text).

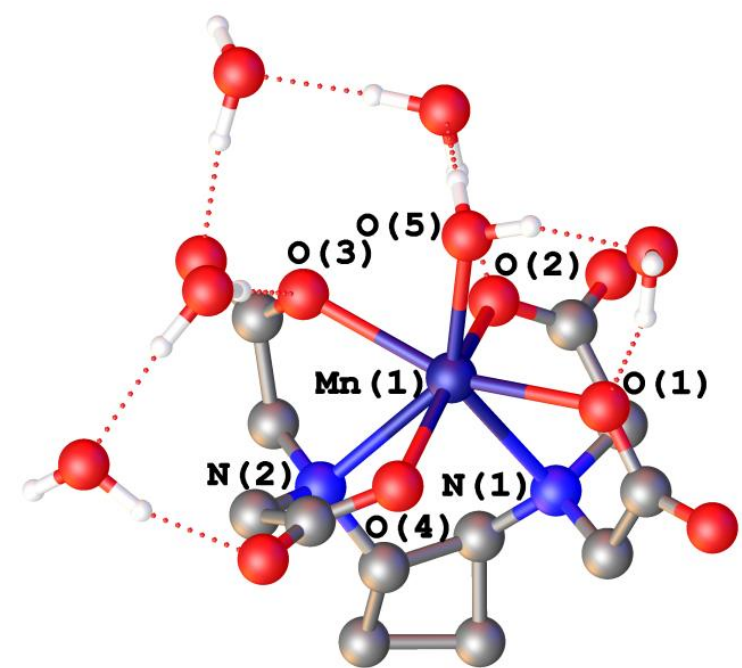

Figure 4. Structure of the $\left[\mathrm{Mn}(\mathrm{L1})\left(\mathrm{H}_{2} \mathrm{O}\right)\right]^{2-} \cdot 5 \mathrm{H}_{2} \mathrm{O}$ system optimized at the $\mathrm{M} 11 /$ def2-TZVP level. Hydrogen atoms bonded to carbon atoms have been omitted for clarity.

Factors affecting complex stabilities and the hyperfine coupling constant $\boldsymbol{A} / \boldsymbol{\hbar}$. In a recent paper, Gale et al. reported a method to determine the hydration number of $\mathrm{Mn}^{2+}$ complexes using transverse ${ }^{17} \mathrm{O}$ NMR measurements. ${ }^{28}$ This method relies on the assumption that the hyperfine coupling constant does not change significantly depending on the co-ligands coordinated to the metal ion. (We should note that this method is not applicable to $[\mathrm{Mn}(\mathbf{L} \mathbf{1})]^{2-}$ since no clear maximum is observable for the temperature-dependent ${ }^{17} \mathrm{O}$ transverse relaxation rates). The data reported in Table 3 show that the $A / \hbar$ values determined by this series of related complexes are relatively similar, with $[\mathrm{Mn}(\mathrm{cdta})]^{2-}$ showing the lowest value $\left(-26.4 \times 10^{6} \mathrm{rad} \mathrm{s}^{-1}\right)^{27}$ and $[\mathrm{Mn}(\mathrm{L1})]^{2-}$ the highest $\left(-37.1 \times 10^{6} \mathrm{rad} \mathrm{s}^{-1}\right)$.

To further analyse the factors that affect $A / \hbar$ values in these complexes, we performed DFT calculations at the M11/def2-TZVP level (see computational details below). In these calculations we used the cluster-continuum approach, in which solvent effects are considered by including a number of explicit water molecules and incorporating a continuum solvation model. ${ }^{30}$ The inclusion of an explicit second-sphere solvation shell is necessary to provide a better description of the bond distances and ${ }^{17} \mathrm{O} A / \hbar$ values of the coordinated water molecule. ${ }^{31}$ Furthermore, this second solvation sphere is also required to study the water exchange of the coordinated water molecule (see below). The optimized structure of the
$\left[\mathrm{Mn}(\mathrm{L1})\left(\mathrm{H}_{2} \mathrm{O}\right)\right]^{2-} \cdot 5 \mathrm{H}_{2} \mathrm{O}$ system is shown in Figure 4 . The cyclobutane unit adopts a puckered conformation to alleviate steric strain, with C-C-C angles in the range 86.4 to $87.8^{\circ}$ (a planar structure is characterised by angles of $\left.90^{\circ}\right) .^{32}$ The conformation adopted by the ligand is typical of edta type ligands, providing a capped trigonal prismatic coordination, in which the coordinated water molecule occupies the capping position. ${ }^{29}$

The same computational approach was used to obtain the optimized structures of the complexes with edta ${ }^{4-}, \mathrm{cdta}^{4-}$ and pyc3a $^{3-}$ (Figures S4-S6, ESI+). The calculated distances of the metal coordination environments are presented in Table S2 $(E S I+)$. The comparison of the distances obtained with DFT and those observed in the X-ray structures of the $[\mathrm{Mn}(\mathrm{cdta})]^{2-}$ and $[\mathrm{Mn}(\text { edta })]^{2-}$ complexes evidences a good agreement between the experimental and calculated data. ${ }^{24}$ In this series, a remarkable difference is observed in the $\mathrm{Mn}-\mathrm{N}$ bond distances which are $\sim 0.08 \AA$ longer for $\left[\mathrm{Mn}\left(\mathrm{L}^{1}\right)\right]^{2-}$ complex than for the other complexes. These relatively long distances are likely responsible for the lower stability of $\left[\mathrm{Mn}\left(\mathrm{L}^{1}\right)\right]^{2-}$ and are associated to the more open bite angle of the diaminocyclobutane spacer. This effect becomes evident upon comparing the $\mathrm{N}-\mathrm{Mn}-\mathrm{N}$ angles involving the amine $\mathrm{N}$ atoms, which amount to $78.6,74.2,73.7$ and $72.9^{\circ}$ for the complexes of $\mathbf{L 1}$, edta ${ }^{4-}$, cdta $^{4-}$ and pyc3a ${ }^{3-}$, respectively.

The optimized structures of the $\left[\mathrm{Mn}\left(\mathrm{L}^{1}\right)\right]^{2-},[\mathrm{Mn}(\text { edta })]^{2-}$, and [Mn(pyc3a)] complexes present very similar distances between the oxygen atom of the coordinated water molecule and the metal ion $\left(r_{\mathrm{MnO}}\right)$, while this distance is slightly longer for $[\mathrm{Mn}(\mathrm{cdta})]^{2-}$. The corresponding $A / \hbar$ values obtained with DFT are also very similar, ranging from $-35.8 \times 10^{6}$ to $-39.8 \times 10^{6} \mathrm{rad}$ $\mathrm{s}^{-1}$ (Table 4). The $\mathrm{Mn}^{-\mathrm{O}_{\text {water }}}$ distances calculated for $[\mathrm{Mn}(\text { edta })]^{2-}$ and $[\mathrm{Mn}(\mathrm{cdta})]^{2-}$ are in good agreement with those observed in the solid state for the ammonium salts (2.241 and $2.272 \AA$, respectively), which also evidence a longer bond in the latter. ${ }^{24}$

To evaluate the impact of $r_{\mathrm{MnO}}$ variation on the values of $A / \hbar$, we performed additional calculations on the $\left[\mathrm{Mn}(\mathbf{L 1})\left(\mathrm{H}_{2} \mathrm{O}\right)\right]^{2-} \cdot 5 \mathrm{H}_{2} \mathrm{O}$ system. The potential energy of this system was investigated by varying the $r_{\mathrm{MnO}}$ distance around the equilibrium value from 2.20 to $2.31 \AA$, using steps of $0.1 \AA$. Furthermore, we also explored the effect of the orientation of the coordinated water molecule with respect to the $\mathrm{Mn}-\mathrm{O}$ axis, which was found to affect the $A / \hbar$ values of $\mathrm{Gd}^{3+}$ complexes. ${ }^{33}$ The orientation of the water molecule can be defined by the angle $\phi$ that form the $M n-O_{\text {water }}$ and $\mathrm{O}_{\text {water }}-\mathrm{C}_{\mathrm{H}}$ vectors, where 
$\mathrm{C}_{\mathrm{H}}$ represents the centroid of the line connecting the two $\mathrm{H}$ atoms of the coordinated water molecule. A $\phi$ angle of $90^{\circ}$ therefore indicates that the bisector of the coordinated water molecule is perpendicular to the $\mathrm{Mn}-\mathrm{O}_{\text {water }}$ vector, while for $\phi$ angle of $180^{\circ}$ the water molecule and the metal ion are on the same plane. The equilibrium structure of $\left[\mathrm{Mn}(\mathbf{L 1})\left(\mathrm{H}_{2} \mathrm{O}\right)\right]^{2-} \cdot 5 \mathrm{H}_{2} \mathrm{O}$ shows a $\phi$ angle of $129.0^{\circ}$. This angle was varied in steps of approximately $0.5^{\circ}$ from 124 to $131^{\circ}$. Thus, the variation of $r_{\mathrm{MnO}}$ and $\phi$ using relaxed potential energy surface scans generated 144 geometries for which the ${ }^{17} \mathrm{O} A / \hbar$ values were calculated.

The results of our DFT calculations show that the absolute value of $A / \hbar$ increases as the $M n-O_{\text {water }}$ distance becomes shorter, as would be expected (Figure 5). A shorter distance favours delocalization of the spin density of the unpaired electrons of the metal ion to the observed nucleus, generating excess of $\alpha$ spin density at the latter. The calculations also show that $A / \hbar$ is affected by the orientation of the water molecule, its absolute value increasing as the $\theta$ angle increases. The analysis of the natural bond orbitals (NBOs) shows that the lone pair of the coordinated water molecule directed to the metal ion possesses an increasing $s$ character as $\phi$ increases. This allows a more efficient pathway for the spin density to sit on the ${ }^{17} \mathrm{O}$ nucleus through spin polarization.
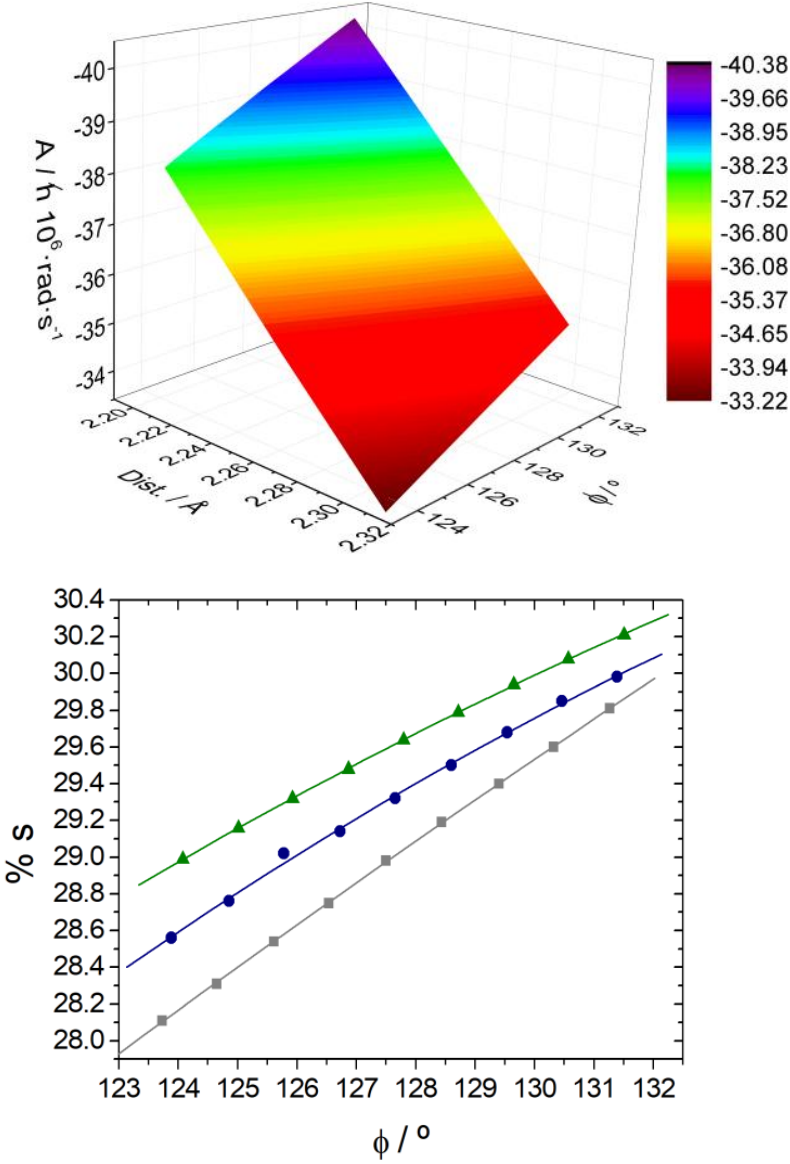

Figure 5. Top: Hyperfine coupling constant $A / \hbar$ calculated for the $\left[\mathrm{Mn}(\mathbf{L 1})\left(\mathrm{H}_{2} \mathrm{O}\right)\right]^{2-} \cdot 5 \mathrm{H}_{2} \mathrm{O}$ system at the M11/def2-TZVP level. Bottom: Variation of the \%s contribution of the water lone pair directed to the metal ion with the tilt angle.
Factors affecting water exchange. The water exchange process in the family of complexes investigated here was further analysed by using DFT calculations. For this purpose, we first explored the potential energy surface of the $\left[\mathrm{Mn}(\mathbf{L 1})\left(\mathrm{H}_{2} \mathrm{O}\right)\right]^{2-} \cdot 5 \mathrm{H}_{2} \mathrm{O}$ system by enlarging the $\mathrm{Mn}-\mathrm{O}_{\text {water }}$ distance in steps of $0.05 \AA$. This eventually led to a second energy minimum in the potential energy surface that lacks any inner-sphere water molecule. The transition state that related the two energy minima was subsequently optimized. Similar calculations provided the transition states characterizing the dissociative mechanism for the $[\mathrm{Mn}(\text { edta })]^{2-},[\mathrm{Mn}(\mathrm{cdta})]^{2-}$ and $\left[\mathrm{Mn}(\text { pyc3a) }]^{-}\right.$complexes. The frequency analysis confirmed the nature of the optimized transition states as saddle points and provided the zero point energies and thermal terms required to calculate the enthalpy and entropy of the systems, giving access to activation parameters. The results are shown in Table 4 . The activation parameters can be subsequently used to estimate the $k_{e x}^{298}$ values, which are also listed in Table 4 . We want to stress that the calculation of exchange rates is a difficult problem, in particular due to the approximations used in the thermochemistry analysis and the limited number of explicit water molecules introduced in our models. Nevertheless, it is gratifying to see that the calculated $k_{e x}^{298}$ values are in rather good agreement with the experimental values.

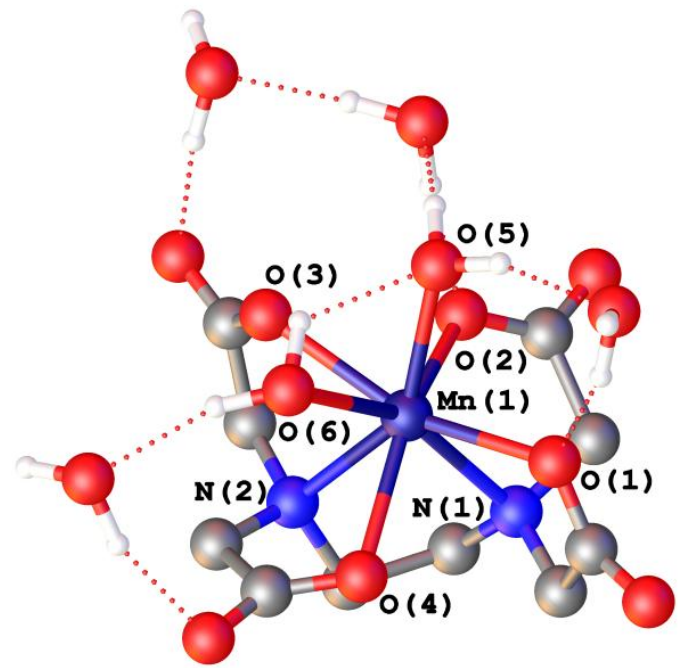

Figure 6. Structure of the transition state characterizing the associative mechanism in $\left[\mathrm{Mn}\left(\text { edta) }\left(\mathrm{H}_{2} \mathrm{O}\right)\right]^{2-} \cdot 5 \mathrm{H}_{2} \mathrm{O}\right.$ system (M11/def2-TZVP level). Hydrogen atoms bonded to carbon atoms have been omitted for clarity. The $\mathrm{Mn}(1)-\mathrm{O}(5)$ and $\mathrm{Mn}(1)-\mathrm{O}(6)$ distances are 2.760 and $2.324 \AA$, respectively).

Our calculations predict positive values for $\Delta S^{\ddagger}$, as expected for dissociative mechanisms, ${ }^{34}$ though smaller than the experimental ones. Furthermore, the $\mathrm{Mn}-\mathrm{O}_{\text {water }}$ distances calculated for the transition states (> $3.3 \AA$ ) are also indicative of a dissociative mechanism, in which the coordinated water molecule leaves the metal coordination environment before the incoming water molecule approaches the metal ion. Attempts to model the associative mechanism failed in all cases, except for the $\left[\mathrm{Mn}(\text { edta })\left(\mathrm{H}_{2} \mathrm{O}\right)\right]^{2-} \cdot 5 \mathrm{H}_{2} \mathrm{O}$ system. In this latter case, we could characterize the transition state responsible for the associative water exchange pathway (Fig 6), in which the entering water 
molecule approaches the metal ion (2.760 ̊̊) while the leaving water molecule is still coordinated (2.324 ̊̊). This transition state leads to a minimum energy structure in which the metal ion is eight-coordinated, with $\mathrm{Mn}-\mathrm{O}_{\text {water }}$ distances of 2.429 and $2.393 \AA$ A. We note that while not very common, well characterized eight-coordinated $\mathrm{Mn}^{2+}$ complexes have been reported. ${ }^{35}$ The corresponding activation parameters (Table 4) are characterized by a negative value of $\Delta S^{\ddagger}$ and a lower value of $\Delta H^{\ddagger}$, as would be expected. ${ }^{36}$ Surprisingly, the dissociative and associative pathways are characterized by similar free energies of activation at $298 \mathrm{~K}$, and thus it is likely that the two of them play a role in water exchange. This would be in agreement with the small positive value of $\Delta S^{\ddagger}$ determined for $\left[\mathrm{Mn}(\text { edta })\left(\mathrm{H}_{2} \mathrm{O}\right)\right]^{2-}$ compared to $\left[\mathrm{Mn}(\mathrm{cdta})\left(\mathrm{H}_{2} \mathrm{O}\right)\right]^{2-}$ (Table 3). Thus, the faster water exchange of the $\left[\mathrm{Mn}(\mathrm{edta})\left(\mathrm{H}_{2} \mathrm{O}\right)\right]^{2-}$ complex is likely related to the presence of both the associative and dissociative water exchange mechanisms. The presence of a rigidifying spacer (cyclobutane or cyclohexane) in the ligand appears to inhibit the associative pathway. The DFT results shown in Table 4 also suggest that the lower exchange rate of $\left[\mathrm{Mn}(\text { pyc3a })\left(\mathrm{H}_{2} \mathrm{O}\right)\right]^{-}$is due to a higher $\Delta H^{\ddagger}$, presumably related to a stronger electrostatic interaction between the coordinated water molecule and the metal ion, due to the reduced overall negative complex charge.

\section{Conclusions}

We have reported a combined experimental (potentiometric, ${ }^{17} \mathrm{O} N M R$ and ${ }^{1} \mathrm{H}$ relaxometric) and theoretical (DFT) study to characterize $\mathrm{Mn}^{2+}$ complexes formed with highly rigid, openchain chelators containing carboxylate or picolinate coordinating functions and a cyclobutane ring in the ligand skeleton. The ligands $\mathbf{L 2}^{\mathbf{4}^{-}}$and $\mathbf{L}^{\mathbf{4}^{-}}$, bearing one or two picolinate functions, respectively, form $\mathrm{Mn}^{2+}$ complexes of a considerably higher thermodynamic stability than the tetracarboxylate analogue $\mathbf{L 1}^{4-}$, as expected on the basis of the increased number of ligand donor atoms of the picolinates. The cyclobutane ring is responsible for the lower stability constant of $[\mathrm{Mn}(\mathrm{L} \mathbf{1})]^{2-}$ as compared to $\left[\mathrm{Mn}(\text { edta) }]^{2-}\right.$ or $[\mathrm{Mn}(\mathrm{cdta})]^{2-}$, and this was also corroborated with DFT calculations which indicate longer $\mathrm{Mn}-\mathrm{N}$ distances and more open N-Mn-N angles for the cyclobutane-derivative. Monohydration of $[\mathrm{Mn}(\mathbf{L 1})]^{2-}$ has been confirmed by NMRD and ${ }^{17} \mathrm{O}$ chemical shift data. The water exchange on $[\mathrm{Mn}(\mathrm{L} \mathbf{1})]^{2-}$ is faster than that on $[\mathrm{Mn}(\text { edta })]^{2-}$ but slower than on $[\mathrm{Mn}(\mathrm{cdta})]^{2-}$.

The DFT study presented here provides insight into different parameters that govern the relaxation properties of $[\mathrm{Mn}(\mathbf{L} \mathbf{1})]^{2-}$ and closely related derivatives. The calculated ${ }^{17} \mathrm{O}$ $A / \hbar$ values present a good agreement with the experimental data and fall in a rather narrow range. The spin density at the ${ }^{17} \mathrm{O}$ nucleus is affected by both the $\mathrm{Mn}-\mathrm{O}_{\text {water }}$ distance and the orientation of the water molecule with respect to the $\mathrm{Mn}-\mathrm{O}_{\text {water }}$ vector. Nevertheless, our calculations indicate that $A / \hbar$ values are little affected by these structural changes, supporting their use to determine the hydration state of $\mathrm{Mn}^{2+}$ complexes. ${ }^{28}$ DFT was also used to estimate the activation parameters for the dissociative pathway of the water exchange reaction in $\left[\mathrm{Mn}\left(\mathrm{L}^{1}\right)\right]^{2-},[\mathrm{Mn}(\text { edta })]^{2-},[\mathrm{Mn}(\text { edta })]^{2-}$ and [Mn(pyc3a)]. The lower water exchange of [Mn(pyc3a) $]^{-}$appears to be related to a higher $\Delta H^{\ddagger}$, associated to a strong interaction between the metal ion and the coordinated water molecule. Our calculations also suggest that the associative pathway plays a role in the water exchange reaction in $[\mathrm{Mn}(\text { edta })]^{2-}$.

\section{Experimental Section}

Sample preparation and potentiometric titrations. $\mathrm{Mn}^{2+}$ concentration was determined by titrating the metal solutions with standardized $\mathrm{Na}_{2} \mathrm{H}_{2}$ EDTA in urotropine buffer $(\mathrm{pH} 5.6-5.8)$ in the presence of xylenol orange as an indicator. The $[\mathrm{MnL}]^{2-}$ complexes were prepared by mixing the ligand and the metal and adjusting the $\mathrm{pH}$ to 7.

Stability constants of complexes and their protonation constants are described and defined in Equations (2) and (3).

$$
\begin{aligned}
K_{M L} & =\frac{[M L]}{[M][L]} \\
K_{M H_{i} L} & =\frac{\left[M\left(H_{i} L\right)\right]}{\left[M\left(H_{i-1} L\right)\right]\left[H^{+}\right]}
\end{aligned}
$$

Where $[\mathrm{M}],[\mathrm{L}]$, and $[\mathrm{ML}]$ are the equilibrium concentrations of free metal ion, deprotonated ligand, and deprotonated complex, respectively. Experimental data were refined using the computer software Hyperquad 2008. ${ }^{37}$ Species distribution plots were calculated taking the experimental constants using the computer software HySs. ${ }^{38}$ The ionic product of water used at $25 \stackrel{\circ}{ } \mathrm{C}_{\text {was }} \mathrm{pK}_{\mathrm{w}}=$ 13.77, while the ionic strength was kept at $0.1 \mathrm{M}$. Fixed values were used for $\mathrm{p} K_{w}$ and total concentrations of metal, ligand, and acid. See ESI† for more details.

${ }^{1} \mathrm{H}$ NMRD and ${ }^{17} \mathrm{O}$ NMR measurements. ${ }^{1} \mathrm{H}$ NMRD profiles of an aqueous $3.29 \mathrm{mM}[\mathrm{Mn}(\mathbf{L 1})]^{2-}$ solution $(\mathrm{pH}=7.4)$ were measured at 25 and $37{ }^{\circ} \mathrm{C}$ on a Stelar SMARTracer Fast Field Cycling NMR relaxometer (0.00024-0.24 T, 0.01-10 MHz, ${ }^{1} \mathrm{H}$ Larmor frequency) and a Bruker WP80 NMR electromagnet adapted to variable field measurements $(0.47-1.88 \mathrm{~T}, 20-80 \mathrm{MHz})$, controlled by the SMARTracer PC-NMR console. The temperature was controlled by a VTC91 temperature control unit and maintained by a gas flow. The temperature was determined by previous calibration with a $\mathrm{Pt}$ resistance temperature probe. To avoid any free $\mathrm{Mn}^{2+}, 15 \% \mathbf{L 1}^{4-}$ excess was used.

Variable-temperature ${ }^{17} \mathrm{O}$ NMR measurements of a $4.9 \mathrm{mM}$ aqueous solution of $[\mathrm{Mn}(\mathbf{L 1})]^{2-}$ at $\mathrm{pH}=7.0$ were performed on a Bruker Advanced $400 \mathrm{MHz}$ spectrometer using a $10 \mathrm{~mm}$ BBFO probe $(9.4 \mathrm{~T}, 54.2 \mathrm{MHz})$ in the temperature range $1-75^{\circ} \mathrm{C}$. The temperature was calculated according to published calibration routines with ethylene glycol and $\mathrm{MeOH}$. Acidified water $\left(\mathrm{HClO}_{4}, \mathrm{pH}\right.$ 3.3) was used as diamagnetic reference. Transverse ${ }^{17} \mathrm{O}$ relaxation times were obtained by the Carl-Purcell-Meiboom-Gill spin-echo technique. To eliminate susceptibility corrections to the chemical shifts, the sample was placed in a glass sphere fixed in a $10 \mathrm{~mm}$ NMR tube. To improve sensitivity, $\mathrm{H}_{2}{ }^{17} \mathrm{O}\left(10 \% \mathrm{H}_{2}{ }^{17} \mathrm{O}\right.$, CortecNet $)$ was added to achieve $\sim 1 \%{ }^{17} \mathrm{O}$ content in the sample. 
Computational details. All calculations described in this work were performed with the Gaussian 16 program package (version B.01). ${ }^{39}$ Full geometry optimisations of the $\left[\mathrm{Mn}(\mathbf{L 1})\left(\mathrm{H}_{2} \mathrm{O}\right)\right]^{2-} \cdot 5 \mathrm{H}_{2} \mathrm{O},[\mathrm{Mn}(\mathbf{L 2})]^{2-}$, $[\mathrm{Mn}(\mathrm{L} \mathbf{L})]^{2-}, \quad\left[\mathrm{Mn}(\mathrm{edta})\left(\mathrm{H}_{2} \mathrm{O}\right)\right]^{2-} \cdot 5 \mathrm{H}_{2} \mathrm{O}, \quad\left[\mathrm{Mn}(\mathrm{cdta})\left(\mathrm{H}_{2} \mathrm{O}\right)\right]^{2-} \cdot 5 \mathrm{H}_{2} \mathrm{O}$ and $\left[\mathrm{Mn}\left(\text { pyc3a) }\left(\mathrm{H}_{2} \mathrm{O}\right)\right]^{-} \cdot 5 \mathrm{H}_{2} \mathrm{O}\right.$ were performed using DFT calculations with the M11 functional, which pertains to the family of hybridmeta GGA functionals. M11 is a range-separated functional of the Minnesota family that uses $100 \%$ Hartree-Fock exchange for large interelectronic distances and $42.8 \%$ at short ranges, and was found to be particularly well suited to compute barrier heights. ${ }^{40}$ In previous works it was shown that functionals of the Minnesota family like M06-2X predicted the correct number of coordinated water molecules in $\left[\mathrm{Mn}(\text { phdta) }]\left(\mathrm{H}_{2} \mathrm{O}\right)\right]^{2-}$, while other functionals such as B3LYP favoured the $q=0$ form, in contrast to the experimental evidence. ${ }^{41}$ All calculations employed the def2-TZVP basis set. ${ }^{42}$ Transition states were located with the aid of the synchronous transit-guided quasi-Newton method. ${ }^{43}, 44$ The exchange rates of the water exchange reactions $\left(k_{\mathrm{ex}}\right)$ were estimated using transition state theory by using Equations (4) and $(5),{ }^{45,46}$ where $k_{\mathrm{B}}, h$ and $R$ are the Boltzmann constant, Planck's constant and the $R$ the gas constant, respectively, $\Delta G^{\ddagger}$ is the free energy difference between the intermediate and the transition state (at $298.15 \mathrm{~K}$ ), $\kappa$ is the transition probability (assumed to be 1 ), $\Gamma_{\mathrm{n}}$ is the tunnelling factor and $v^{\ddagger}$ is the imaginary frequency characterizing the transition state.

$$
\begin{aligned}
& k_{e x}=\Gamma_{n} \kappa \frac{k_{B} T}{h} e^{-\Delta G^{\ddagger} / R T} \\
& \Gamma_{n}=1+24\left(\frac{h v^{\ddagger}}{k_{B} T}\right)^{2}
\end{aligned}
$$

The nature of the energy minima and transition states was confirmed with frequency analysis. Bulk solvent effects (water) were considered with the integral equation formalism variant of the polarizable continuum model (IEFPCM). ${ }^{47}$ Natural bond orbital (NBO) analysis was carried out with the NBO program (version 3.1), ${ }^{48,49}$ as included in Gaussian.

\section{Conflicts of interest}

There are no conflicts to declare.

\section{Acknowledgements}

O.P.-T. thanks Universitat Autònoma de Barcelona for a predoctoral fellowship and for a travel grant. Financial support from Spanish Ministerio de Economía y Competitividad (grant CTQ201677978-R, AEI/FEDER, UE) is gratefully acknowledged. C. P.-I. and D. E.-G. thank Centro de Supercomputación de Galicia (CESGA) for providing the supercomputing facilities.

\section{References}

1 (a) The Chemistry of Contrast Agents in Medical Magnetic Resonance Imaging, second Ed.; A. Merbach, L. Helm and E. Tóth, Eds.; Wiley, Weinheim, 2013; (b) Theranostics and Image Guided Drug Delivery; M. Thanou, Ed; RSC, Cambridge, 2018.
See, for instance (a) T. Grobner, Nephrol. Dial. Transplat., 2006, 21, 1104; (b) T. Kanda, T. Fukusato, M. Matsuda, K. Toyoda, H. Oba, J. Kotoku, T. Haruyama, K. Kitajima and S. Furui, Radiology, 2015, 276, 228; (c) R. J. McDonald, J. S. McDonald, D. F. Kallmes, M. E. Jentoft, D. L. Murray, K. R. Thielen, E. E. Williamson and L. J. Eckel, Radiology, 2015, 275, 772.

3 E. M. Gale, I. P. Atanasova, F. Blasi, I. Ay and P. Caravan, J. Am. Chem. Soc., 2015, 137, 15548.

4. I. Bertini, F. Briganti, Z. Xia and C. Luchinat, J. Magn. Reson., 1993, 101, 198.

5 (a) D. Pan, A. H. Schmiedr, S. A. Wickline and G. M. Lanza, Tetrahedron, 2011, 67, 8431.(b) B. Drahos, I. Lukes and E. Toth, Eur. J. Inorg. Chem., 2012, 1975; (c) M. Kueny-Stotz, A. Garafolo and D. Felder-Flesh, Eur J. Inorg. Chem., 2012, 1987.

6 (a) E. Molnár, N. Camus, V. Patinec, G. A. Rolla, M. Botta, G. Tircsó, F. K. Kálmán, T. Fodor, R. Tripier and C. Platas-Iglesias, Inorg. Chem., 2014, 53, 5136; (b) A. Rodríguez-Rodríguez, Z. Garda, E. Ruscsák, D. Esteban-Gómez, A. De Blas, T. RodríguezBlas, L. M. P. Lima, M. Beyler, R. Tripier, G. Tircsó, C. PlatasIglesias, Dalton Trans., 2015, 44, 5017; (c) R. Pujales-Paradela, F. Carniato, R. Uzal-Varela, I. Brandariz, E. Iglesias, C. PlatasIglesias, M. Botta and D. Esteban-Gómez, Dalton Trans., 2019, 48, 696.

7 (a) C. Vannaschen, E. Molnár, G. Tircsó, F.K. Kálmán, E. Tóth, M. Brandt, H. H. Coenen and B. Neumaier, Inorg. Chem., 2017, 56, 7746; (b) Z. Garda, E. Molnár, F. K. Kálmán, R, Botár, V. Nagy, Z. Baranyai, E. Brücher, Z. Kovács, I. Tóth, G. Tircsó, Front. Chem., 2018, 6, 14; (c) M. Botta, F. Carniato, D. Esteban-Gómez, C. Platas-Iglesias, L. Tei, Future Med. Chem., 2019, 11, 1461; (d) R. Botár, E. Molnár, G. Trencsény, J. Kiss, F. K. Kálmán, G. Tircsó, J. Am. Chem. Soc., 2020, 142, 1662;

8 G. A. Rolla, C. Platas-Iglesias, M. Botta, L. Tei and L. Helm, Inorg. Chem., 2013, 52, 3268.

9 S. Aime, M. Botta, D. Esteban-Gómez and C. Platas-Iglesias, Mol. Phys., 2018, 117, 898.

10 D. J. Erstad, I. A. Ramsay, V. C. Jordan, M. Sojoodi, B. C. Fuchs, K. K. Tanabe, P. Caravan and E. M. Gale, Invest. Radiol., 2019, 54, 697.

11 D. Ndiaye, M. Sy, A. Pallier, S. Même, I. De Silva, S. Lacerda, A. M. Nonat, L. J. Charbonnière and E. Tóth, Angew. Chem. Int. Ed., 2020, 59, 12223.

12 O. Porcar-Tost, J. A. Olivares, A. Pallier, D. Esteban-Gómez, O. Illa, C. Platas-Iglesias, É. Tóth and R. M. Ortuño, Inorg. Chem., 2019, 58, 13170.

13 G. Tircsó, M. Regueiro-Figueroa, V. Nagy, Z. Garda, T. Garai, F. K. Kálmán, D. Esteban-Gómez, É. Tóth, C. Platas-Iglesias, Chem. Eur. J., 2016, 22, 896.

14 (a) B. Phukan, C. Mukherjee, U. Goswami, A. Sarmah, S. Mukherjee, S. K. Sahoo, S. Ch. Moi Inorg. Chem., 2018, 57, 2631; (b) M. Khannam, T. Weyhermüller, U. Goswami, C. Mukherjee, Dalton Trans., 2017, 46, 10426.

15 F. K. Kálmán and G. Tircsò, Inorg. Chem., 2012, 51, 10065.

16 E. M. Gale, S. Mukherjee, C. Liu, G. S. Loving and P. Caravan, Inorg. Chem., 2014, 53, 10748.

17 E. M. Gale, I. P. Atanasova, F. Blasi, I. Ay and P. Caravan, J. Am. Chem. Soc., 2015, 137, 15548.

18 A. Bianchi, L. Calabi, C. Giorgi, P. Losi, P. Mariani, D. Palano, P. Paoli, P. Rossi and B. Valtancoli, J. Chem. Soc., Dalton Trans., 2001, 917.

19 B. Drahos, J. Kotek, P. Hermann, I. Lukes and E. Tóth, Inorg. Chem., 2010, 49, 3224 
20 D. Esteban-Gómez, C. Cassino, M. Botta and C. Platas-Iglesias, RSC Adv., 2014, 4, 7094.

21 L. Banci, I. Bertini and C. Luchinat, Inorg. Chim. Acta, 1985, 100, 173.

22 E. Balogh, Z. He, W. Hsieh, S. Liu and É. Tóth, Inorg. Chem., 2007, 46, 238.

23 J. A. Peters and C. F. G. C. Geraldes, Inorganics, 2018, 6, 116.

24 X. F. Wang, J. Gao, J. Wang, Zh. H. Zhang, Y. F. Wang, L. J. Chen, W. Sun and X. D. Zhang, J. Struct. Chem., 2008, 49, 724.

25 Y. Ducommun, K. E. Newman and A. E. Merbach, Inorg. Chem., 1980, 19, 3696.

26 (a) T. J. Swift and R. E. Connick, J. Chem. Phys., 1962, 37, 307; (b) T. J. Swift and R. E. Connick, J. Chem. Phys., 1964, 41, 2553.

27 J. Maigut, R. Meier, A. Zahl and R. van Eldik, J. Am. Chem. Soc., 2008, 130, 14556.

28 E. M. Gale, J. Zhu and P. Caravan, J. Am. Chem. Soc., 2013, 135, 18600.

29. J. Maigut, R. Meier, A. Zahl and R. van Eldik, Inorg. Chem., 2008, 47, 5702 .

30 V. S. Bryantsev, M. S. Diallo and W. A. Goddart III, J. Phys. Chem. B, 2008, 112, 9709 .

31 V. Patinec, G. A. Rolla, M. Botta, R. Tripier, D. Esteban-Gómez and C. Platas-Iglesias, Inorg. Chem., 2013, 52, 11173.

32 V. Dragojlovic, ChemTexts, 2015, 1, 14.

33 D. Esteban-Gómez, A. de Blas, T. Rodríguez-Blas, L. Helm and C. Platas-Iglesias, ChemPhysChem, 2012, 13, 3640.

34 C. D. Hubbard and R. van Eldik, Inorg. Chim Acta, 2010, 363, 2357.

35 K. S. Hagen, Angew. Chem Int. Ed., 1992, 31. 764.

36 L. Helm and A. E. Merbach, Chem. Rev., 2005, 105, 1923.

37 P. Gans, A. Sabatini and A. Vacca, Talanta 1996, 43, 1739.

38 L. Alderighi, P. Gans, A. lenco, D. Peters, A. Sabatini and A. Vacca, Coord. Chem. Rev. 1999, 184, 311.

39 Gaussian 16, Revision B.01, M. J. Frisch, G. W. Trucks, H. B. Schlegel, G. E. Scuseria, M. A. Robb, J. R. Cheeseman, G. Scalmani, V. Barone, G. A. Petersson, H. Nakatsuji, X. Li, M. Caricato, A. V. Marenich, J. Bloino, B. G. Janesko, R. Gomperts, B. Mennucci, H. P. Hratchian, J. V. Ortiz, A. F. Izmaylov, J. L. Sonnenberg, D. Williams-Young, F. Ding, F. Lipparini, F. Egidi, J. Goings, B. Peng, A. Petrone, T. Henderson, D. Ranasinghe, V. G. Zakrzewski, J. Gao, N. Rega, G. Zheng, W. Liang, M. Hada, M. Ehara, K. Toyota, R. Fukuda, J. Hasegawa, M. Ishida, T. Nakajima, Y. Honda, O. Kitao, H. Nakai, T. Vreven, K. Throssell, J. A. Montgomery, Jr., J. E. Peralta, F. Ogliaro, M. J. Bearpark, J. J. Heyd, E. N. Brothers, K. N. Kudin, V. N. Staroverov, T. A. Keith, R. Kobayashi, J. Normand, K. Raghavachari, A. P. Rendell, J. C. Burant, S. S. Iyengar, J. Tomasi, M. Cossi, J. M. Millam, M. Klene, C. Adamo, R. Cammi, J. W. Ochterski, R. L. Martin, K. Morokuma, O. Farkas, J. B. Foresman, and D. J. Fox, Gaussian, Inc., Wallingford CT, 2016.

40 R. Peverati and D. G. Truhlar, J. Phys. Chem. Lett., 2011, 2, 2810.

41 K. Pota, Z. Garda, F. K. Kálmán, J. L. Barriada, D. Esteban-Gómez, C. Platas-Iglesias, I. Tóth, E. Brücher and G. Tircsó, New J. Chem., 2018, 42, 8001.

42 F. Weigend and R. Ahlrichs, Phys. Chem. Chem. Phys., 2005, 7, 3297.

43 C. Peng, P. Y. Ayala, H. B. Schlegel, M. J.; Frisch, J. Comput. Chem., 1996, 17, 49.

44 C. Peng, H. B. Schlegel, Isr. J. Chem., 1994, 33, 449.

45 K. J. Laidler and M. C. King, J. Phys. Chem., 1983, 87, 2657.

46 E. Wigner, J. Chem. Phys., 1937, 5, 720.
47 J. Tomasi, B. Mennucci and R. Cammi, Chem. Rev., 2005, 105, 2999.

48 A. E. Reed, R. B. Weinstock and F. Weinhold, J. Chem. Phys., $1985,83,735$.

49 NBO, version 3.1, E. D. Glendening, A. E. Reed, J. E. Carpenter and F. Weinhold. 